\title{
PENGARUH SOSIAL MEDIA KOMUNIKASI INTERPERSONAL IBU DAN ANAK DALAM MEMBANGUN MOTIVASI BELAJAR
}

\section{THE EFFECT OF SOCIAL MEDIA INTERPERSONAL COMMUNICATION MOTHER AND CHILD TO BUILD LEARNING MOTIVATION}

\author{
DR Pratama1a, IA Ratnamulyani², M Fitriah² \\ ${ }^{1}$ Alumni Ps. Ilmu Komunikasi, Fakultas Ilmu Sosial dan Ilmu Politik, Universitas Djuanda Bogor, \\ ${ }^{2}$ Dosen Program Studi Ilmu Komunikasi, Fakultas Ilmu Sosial dan Ilmu Politik, Universitas Djuanda \\ Bogor, \\ Jl. Tol Ciawi No.1 Kotak Pos 35 Bogor 16720 \\ a Korespondensi: Devi Rachmat Pratama, Email: devi.rachmat@gmail.com
}

(Diterima: 07-08-201; Ditelaah: 13-08-2015; Disetujui: 24-08-2015)

\begin{abstract}
The purpose of this study was to determine (1) how social media influence interpersonal communication in the mother and child to build motivation to learn (2) how much social media influence interpersonal communication in the mother and child to build motivation to learn. This study uses quantitative research methods with survey method and correlation analysis with the help of a questionnaire. This research was conducted at the Villa Mutiara Lido Block F Bogor and samples in this study were 35 respondents, that are children from age 10 to 17 years, who use Blackberry Massengger as a means of communication with the mother. This study shows that social media is influenced by interpersonal communication openness, empathy, support, positivity and equality, while the motivation to learn is influenced by the success, the needs, expectations, rewards, learning activities, and learning environment. To scale the effect that the value of the correlation coefficient ( $r$ ) of 0.239 which is in a low level, it can be concluded that the correlation between the two variables $X$ (social media interpersonal communication) and $Y$ (motivation to learn) has a low correlation and showed a negative relationship.
\end{abstract}

keywords: social media, interpersonal communication, motivation to learn

\begin{abstract}
ABSTRAK
Tujuan dari penelitian ini adalah mengetahui (1) bagaimana pengaruh sosial media komunikasi interpersonal ibu dan anak dalam membangun motivasi belajar (2) seberapa besar pengaruh sosial media komunikasi interpersonal ibu dan anak dalam membangun motivasi belajar. Penelitian ini menggunakan metode penelitian kuantitatif dengan metode survey dan analisis korelasional dengan bantuan kuesioner. Penelitian ini dilakukan di Villa Mutiara Lido Blok F Bogor serta sampel pada penelitian ini sebanyak 35 responden, yaitu anak dari umur 10 sampai 17 tahun, yang menggunakan Blackberry Massengger sebagai alat komunikasi dengan ibu. Penelitian ini menunjukan bahwa sosial media komunikasi interpersonal dipengaruhi oleh keterbukaan, empati, dukungan, kepositifan dan kesamaan, sementara motivasi belajar dipengaruhi oleh keberhasilan, kebutuhan, harapan, penghargaan, kegiatan dalam belajar, dan lingkungan belajar. Untuk besaran pengaruh diperoleh nilai koefisien korelasi (r) sebesar 0,239 yang berada di level rendah, maka dapat disimpulkan bahwa korelasi diantara kedua variabel X (sosial media komunikasi interpersonal) dan variabel Y (motivasi belajar) memiliki hubungan yang rendah dan menunjukan hubungan negatif.
\end{abstract}

Kata Kunci : sosial media, komunikasi interpersonal, motivasi belajar

DR Pratama, IA Ratnamulyani, M Fitriah. 2015. Pengaruh Sosial Media Komunikasi Interpersonal Ibu 2dan Anak dalam Membangun Motivasi Belajar. Jurnal Komunikatio 1(2): 115-134. 


\section{PENDAHULUAN}

Semakin populernya media sosial di lingkungan keluarga membuat komunikasi keluarga menjadi instant, atau keluarga tidak perlu lagi bertatap muka untuk melakukan komunikasi. Namun, disadari atau tidak komunikasi semacam ini memiliki pengaruh yang buruk terhadap komunikasi interpersonal ibu dan anak. Jika ibu dan anak telah melakukan percakapan dalam bentuk texting tentu ini membuat komunikasi interpersonal ibu dan anak tidak berjalan dengan baik, sebab media sosial telah menggantikan interaksi yang intim yang seharusnya terjadi antar ibu dan anak.

Salah satu media sosial yang populer di Indonesia adalah Blackberry Messengger (BBM). Disadari atau tidak penggunaan sosial media tidak selamanya memberi efek positif bagi manusia, terutama bagi seorang anak. Tanpa bimbingan dari orang tua anak memiliki kecenderungan untuk langsung menerima apa yang dia lihat tanpa ada penyaringan informasi yang baik atau buruk bagi dirinya. Tanpa adanya pengawasan yang yang intens dari orang tua, anak akan menjadi malas untuk belajar jika terus berada di dunia sosial media. Bukan hanya malas belajar dalam arti menghapal dan memahami pelajaran di sekolah namun juga anak akan malas untuk belajar berkomunikasi di dunia nyata. Pengguna BBM tidak hanya merambah pada kalangan anak ataupun remaja saja namun juga telah masuk pada kalangan orang tua. Salah satu yang banyak menggunakan BBM adalah dari kalangan ibu.

Seluruh ibu di dunia tentu berharap agar anaknya dapat tumbuh berkembang secara fisik maupun mental. Selain itu ibu berharap anaknya dapat berprestasi. Prestasi yang memuaskan dapat diraih oleh setiap anak jika mereka dapat belajar secara wajar, terhindar dari berbagai hambatan, gangguan maupun ancaman. Namun terkadang, ibu memaksakan kehendak mereka pada anak tanpa mengetahui kebutuhannya. Hal ini menyebabkan ibu banyak menuntut anak harus melakukan sesuai apa yang diinginkan dan dikehendakinya. Salah satu tuntutan dari seorang ibu adalah agar anaknya rajin belajar.
Hal yang terpenting agar anak mau belajar adalah motivasi, pada saat ini sering kali seorang anak membolos sekolah di jam tertentu, hal ini merupakan salah satu perwujudan dari kurangnya motivasi belajar. Pada saat ditanya terkadang mereka menjawab bosan dengan mata pelajarannya. Dalam hal ini kebosanan menjadi indikasi rendahnya motivasi belajar pada anak. Hal ini tentu dapat merugikan anak, sehingga dia tidak dapat mengikuti pelajaran dengan baik. Pada usia terntu seorang ibu harus mampu mengusai cara berkomunikasi sesuai dengan tahap perkembangan anak. Terutama pada usia 10 hingga 17 tahun anak telah masuk pada periode sekolah latin, yaitu sekolah memiliki peranan yang besar dalam membangun motivasi anak. Selain itu pada masa ini anak diajarkan pada bahasa kebudayaan yang dianggap paling kaya dan paling tinggi kedudukannya. Bahasa tersebut perlu diajarkan kepada anak-anak, agar anak-anak dapat mencapai taraf "beradab" dan "berbudaya". (John A Cornenius dalam Kartono:2007).

Adanya komunikasi yang benar tentu anak akan mudah untuk menyerap segala sesuatu yang akan diajarkan oleh orang tua terutama seorang ibu. Hal ini pasti menjadi tugas yang tidak mudah untuk dilakukan oleh seorang ibu, namun itulah peran seorang ibu untuk terus mendidik, merawat, dan melindungi keluarga terutama seorang anak. Rumusan masalah yang dikaji dalam penelitian ini adalah (1) Bagaimana pengaruh sosial media komunikasi interpersonal ibu dan anak dalam membangun motivasi belajar pada anak di Villa Mutiara Lido Bogor? (2) Seberapa besar pengaruh sosial media komunikasi interpersonal ibu dan anak dalam membangun motivasi belajar pada anak di Villa Mutiara Lido Bogor?. Tujuan penelitian ini adalah (1) Mengetahui pengaruh sosial media komunikasi interpersonal ibu dan anak dalam membangun motivasi belajar pada anak di Villa Mutiara Lido Bogor, (2) Mengetahui seberapa besar pengaruh sosial media komunikasi interpersonal ibu dan anak dalam membangun motivasi belajar pada anak di Villa Mutiara Lido Bogor. 


\section{Kerangka Pemikiran}

Penelitian tentang sosial media komunikasi interpersonal ibu dan anak dalam membangun motivasi belajar ini menggunakan acuan konsep Miftah Thoha:2009 komunikasi interpersonal dapat efektif dengan 5 hal berikut (1) keterbukaan yaitu aspek keinginan agar dapat terbuka dengan orang lain dan dapat menanggapi secara jujur informasi yang datang, (2) Empati yaitu mencoba merasakan dan mengerti perasaan orang lain, (3) dukungan yaitu sikap mendukung dengan bersikap (a) deskriptif, bukan efaluatif, (b) spontan, bukan strategi, dan (c) provosional bukan sangat yakin, (4) kepositifan yaitu hal yang dapat berhasil jika mendapat perhatian yang positi, terpelihara dengan baik, dan perasaan positif dapat bermanfaat bagi kerjasama, (5) Kesamaan yaitu tidak selamanya perbedaan akan menganggu komunikasi,
Sosial Media Komunikasi

Interpersonal

Variabel Independen (X)

$$
\begin{aligned}
& \mathrm{X}_{1}: \text { Keterbukaan } \\
& \mathrm{X}_{2}: \text { Empati } \\
& \mathrm{X}_{3}: \text { Dukungan } \\
& \mathrm{X}_{4}: \text { Kepositifan } \\
& \mathrm{X}_{5}: \text { Kesamaan }
\end{aligned}
$$

namun dengan memperhatikan kesamaan kepribadian komunikasi akan tetap berjalan.

Uno (2008) terdapat enam indikator untuk membangun motivasi belajar yaitu (1) keberhasilan yaitu terdapat hasrat dan keinginan agar berhasil yang disebut motif berprestasi, (2) kebutuhan yaitu dorongan akan kebutuhan belajar diakibatkan karena takut akan kegagalan, (3) harapan yaitu harapan didasari bahwa apa yang mereka perbuat akan menggambarkan hasil yang akan diperoleh, (4) penghargaan yaitu pernyataan verbal maupun non verbal seperti "bagus" ataupun pelukan akan membuat motivasi semakin tumbuh, (5) kegiatan dalam belajar yaitu simulasi maupun permainan menjadi hal yang menarik, sehingga dapat menumbuhkan motivasi belajar, (6) lingkungan belajar yaitu lingkungan yang nyaman serta interaksi yang terjalin baik dapat membangun motivasi belajar.

\section{Motivasi Belajar \\ Variabel Dependen}

(Y)
Y1 : Keberhasilan

Y2: Kebutuhan

Y3 : Harapan

Y4 : Penghargaan

Y5 : Kegiatan Belajar

Y6 : Lingkungan Belajar

Gambar 1 Pengaruh sosial media komunikasi interpersonal ibu dan anak dalam membangun motivasi belajar di Villa Mutiara Lido Blok F Bogor.

\section{METODELOGI PENELITIAN}

Pada penelitian ini pendekatan yang digunakan adalah penelitian kuantitatif dengan metode survey dan analisis korelasional. Metode penelitian survey adalah satu bentuk teknik penelitian di mana informasi dikumpulkan dari sejumlah sampel berupa orang, melalui pertanyaan-pertanyaan. Sementara metode analisis korelasional adalah suatu penelitian untuk mengetahui hubungan dan tingkat hubungan antara dua variabel atau lebih tanpa ada upaya untuk mempengaruhi variabel tersebut sehingga tidak terdapat manipulasi variabel (Faenkel dan Wallen, 2008).
Sedangkan penelitian dengan metode survey dengan tekhnik korelasional adalah metode yang dilakukan untuk menggambarkan peristiwa yang telah atau sedang terjadi. Di dalam penelitian ini peneliti bermaksud melihat seberapa besar pengaruh sosial media komunikasi interpersonal ibu dan anak terhadap membangun motivasi belajar. Lokasi penelitian di Villa Mutira Lido Blok F9 RT 25/005 kecamatan Cigombong, Kabupaten Bogor.

Populasi dalam penelitian ini adalah anakanak dengan jenjang pendidikan SD, SMP, dan SMA/SMK dari umur 10 sampai 17 tahun yang menggunakan Blackberry Massengger sebagai alat komunikasi dengan ibu di Villa Mutiara 
Lido Blok F. Populasi adalah wilayah generalisasi yang terdiri atas obyek-obyek yang mempunyai kualitas dan karakteristik tertentu yang ditetapkan oleh peneliti yang dipelajari dan kemudian ditarik kesimpulannya (Sugiono, 2011).

Menurut Gay (dalam Hasan, 2002), penentuan jumlah responden dilakukan dengan pertimbangan representasi dan keadaan khalayak pada umumnya dan merupakan ukuran yang dapat diterima dan memenuhi syarat suatu metode penelitian (minimal 30 orang) untuk jenis korelasional. Sampel dalam penelitian ini adalah 35 responden, yaitu anak dari umur 10 sampai 17 tahun, yang menggunakan Blackberry Massengger sebagai alat komunikasi dengan ibu di Villa Mutiara Lido Blok F. Teknik sampel yang digunakan adalah teknik non-probability sampling bahwa setiap anggota populasi memiliki peluang nol. Peneliti membuat kriteria tertentu siapa yang dijadikan sebagai informan, adapun kriteria yang ditentukan oleh peneliti dalam penelitian ini yaitu ibu dan anak yang aktif menggunakan Blackberry Messengger sebagai alat komunikasi.

Analisa data dalam penelitian ini dilakukan dengan langkah sebagai berikut :

1) Data Primer
Perolehan data melalui teknik wawancara, observasi dan penyebaran kuesioner yang memang bertujuan memperoleh informasi yang disesuaikan dengan rumusan masalah dan tujuan penelitian yang telah ditentukan.

2) Data Sekunder

Perolehan data melalui pencarian informasi yang berkaitan dengan penelitian yang dilakukan, meliputi riset perpustakaan yang berhubungan dengan bidang yang diteliti seperti buku, majalah, artikel, dokumen, dan berbagai literatur yang melengkapi kebutuhan dalam penguatan penelitian.

Perolehan analisis data dan penarikan kesimpulan dilakukan dengan menggunakan statistik sederhana dan dapat diterjemahkan data kuantitatif dengan ditentukan kriteria penilaian berdasarkan skor variasi jawaban. Dari pemberian skor terhadap setiap alternatif jawaban diperoleh variasi jawaban yang bergerak 1 sampai 5 . Untuk menentukan kriteria penilaian maka dicari interval masingmasing skor jawaban, yakni interval dari satu kriteria dengan kriteria yang lainnya diperoleh angka sebesar 0,8. Angka tersebut diperoleh, setelah adanya pengurangan dari nilai tertingi dikurangi nilai terendah dan dibagi dengan banyaknya alternatif jawaban, yang dalam bentuk angkanya ditulis sebagai berikut:

Tabel 1 Penafsiran Hasil Jawaban Berdasarkan Weight Mean Score (WMS)

\begin{tabular}{|c|c|}
\hline Interval angka penafsiran & Kriteria penilaian \\
\hline $0,6-1,4$ & Tidak Baik \\
\hline $1,5-2,3$ & Kurang Baik \\
\hline $2,4-3,2$ & Cukup baik \\
\hline $3,3-4,1$ & Baik \\
\hline $4,2-5,0$ & Sangat baik \\
\hline
\end{tabular}

3)

diperoleh angka interval dengan skala diatas, sebelum melakukan deskripsi, untuk memudahkan perhitungan maka peneliti membuat tabel rekapitulasi jawaban responden sebagai bahan pegangan peneliti untuk melakukan deskripsi dalam memperoleh kesimpulan penelitian.

4) Pembuatan analisa data menggunakan rumus Bakrie Siregar (1981) dalam menentukan perolehan angka kriteria penafsiran dengan interval penafsiran seperti disebutkan diatas dengan rumus sebagai berikut :

Dalam penelitian ini, penulis menggunakan Skala Likert (Sugiyono, 2012) yaitu skala yang digunakan untuk melakukan pengukuran terhadap data ordinal seperti variabel sikap dan pendapat. Skala pengukuran ini bertujuan untuk mengkualifikasi data dari reliabilitasnya suatu variabel.

Teknik pengambilan sampel pada umumnya dilakukan secara random, pengumpulan data menggunakan instrumen penelitian, analisis 
data bersifat kuantitatif/statistik dengan tujuan untuk menguji hipotesis yang telah ditetapkan (Sugiyono, 2012). Dalam penelitian analisis data yang digunakan untuk menjawab permasalahan utama atau pengujian hipotesis adalah Pearson's Correlation (Product Moment), berikut adalah rumusnya:

Analisis data dalam penelitian ini menggunakan Pearson's Correlation (product moment). Rumus statistik ini digunakan untuk mengetahui koefisien korelasi atau derajat kekuatan hubungan dan membuktikan hipotesis hubungan antara variabel/data/skala interval dengan interval lainnya.

$$
r_{x y}=\frac{n \sum X Y-\sum X \sum Y}{\sqrt{\left[n \sum x^{2}-\left(\sum x^{2}\right)\right]\left[n \sum Y^{2}-\left(\sum Y\right)^{2}\right]}}
$$

Keterangan :

$r$ : Pearsen $r$ correlation coefficient

$\mathrm{n}$ : Jumlah sampel

Setelah melewati tahap perhitungan, maka untuk mengetahui tingkat hubungan antara dua variabel (X dan $Y$ ) digunakan pedoman Interpretasi Koefisien Korelasi menurut kategori Sugiyono (2012) berikut ini:

Tabel 2 Interpretasi Koefisien Korelasi

\begin{tabular}{|c|c|}
\hline Interval Koefisien & Tingkat Hubungan \\
\hline $0,00-0,199$ & Sangat Rendah \\
\hline $0,20-0,399$ & Rendah \\
\hline $0,40-0,599$ & Sedang \\
\hline $0,60-0,799$ & Kuat \\
\hline $0,80-1,000$ & Sangat Kuat \\
\hline
\end{tabular}

Untuk mengetahui signifikansi perhitungan korelasi, maka hasil korelasi Pearson's Correlation perlu digunakan uji t menggunakan rumus statistik : $t=r s \sqrt{\frac{N-2}{1-r s^{2}}}$

Melakukan uji hipotesis dari penelitian dalam hal ini dilakukan pengujian statistik terhadap Ho, yaitu : $r s=0, \mathrm{Hi}: \mathrm{rs} \neq 0$, dimana kriteria untuk menerima atau menolak hipotesis yang diajukan adalah jika :

a. Jika thitung $<t_{\text {tabel, }}$ maka Hipotesis nol (Ho) diterima dan Hipotesis alternatif (Ha)

\section{HASIL DAN PEMBAHASAN}

Pada penelitian yang menjadi sasaran penelitian ini adalah ibu dan anak 10-17 tahun ditolak, yang artinya Ho : $\mathrm{rs}=0$ (tidak terdapat pengaruh yang nyata antara sosial media komunikasi interpersonal ibu dan anak dengan motivasi belajar)

b. Jika $t_{\text {hitung }}>t_{\text {tabel, }}$, maka Hipotesis nol (Ho) ditolak dan Hipotesis alternatif (Ha) diterima, yang artinya $\mathrm{Ha}: \mathrm{r} s \neq 0$ (terdapat pengaruh yang nyata antara sosial media komunikasi interpersonal ibu dan anak dengan motivasi belajar).

yang menggunakan Blackberry Messengger. Adapun jumlah serta jenjang pendidikan koresponden penelitian ini adalah sebagai berikut :

Tabel 3 Jumlah koresponden

\begin{tabular}{|c|c|c|}
\hline No & Jenjang Pendidikan & Jumlah Koresponden \\
\hline 1 & SD & 5 anak \\
\hline 2 & SMP & 13 anak \\
\hline 3 & SMA & 17 anak \\
\hline \multicolumn{2}{|c|}{ Jumlah Total } & 35 anak \\
\hline
\end{tabular}


Selain itu terdapat perbedaan penggunaan BBM pada setiap jenjang pendikan:

Tabel 4 Rata-rata penggunaan blackberry messengger

\begin{tabular}{|c|c|c|}
\hline No & Jenjang Pendidikan & Rata-Rata Penggunaan BBM \\
\hline 1 & SD & 2,2 Jam \\
\hline 2 & SMP & 3,6 Jam \\
\hline 3 & SMA & 3,5 Jam \\
\hline
\end{tabular}

Sebelum menguji hipotesis, maka data primer yang telah terkumpul dari hasil penelitian yang dilakukan terhadap ibu dan anak di Villa Mutiara Lido Blok F, selanjutnya dideskripsikan dengan metode distribusi frekuensi terhadap semua peubah penelitian (variabel penelitian).

\section{Sosial Media Komunikasi Interpersonal}

Sosial media komunikasi interpersonal yang dimaksud adalah faktor-faktor apa saja yang mempengaruhi terjadinya komunikasi interpersonal antara ibu dan anak dengan menggunakan sosial media khusunya Blackberry Messengger. Dalam hal ini untuk mempermudah diuraikan menjadi indikator, yakni keterbukaan (tabel 7-8), empati (tabel 9), dukungan (tabel 10-11), kepostifan (tabel 1214), dan kesamaan (tabel 15-16).

\section{a. Keterbukaan}

"Saya sering terbuka kepada anak, tetapi tidak semua hal,kalo masalah pribadi yang ga harus diceritain ke anak ya saya ga bakalan terbuka. Misal jika anak ada masalah maka saya tentu akan terbuka ngasih pendapat saya. Atau ketika anak BBM anak mau pergi kesini, saya akan bilang boleh atau enggak dengan alasan yang jelas. Saya bilang jujur ke anak kalo saya suka ya saya bilang kalo enggak ya bilang tapi pakai alasan yang jelas" - Ibu Ade. Pada indikator keterbukaan terdapat dua item, yaitu : Ibu dapat terbuka terhadap anak, Keterbukaan dalam hal ini meliputi keterbukaan ibu kepada anak dalam mengungkapkan pendapat.

Tabel 5 Keterbukaan - ibu mudah mengungkapkan pendapat

\begin{tabular}{|c|c|c|c|c|c|}
\hline No & Alternatif Jawaban & $f$ & $\mathbf{X}$ & $f(x)$ & $\sum f(x) / N$ \\
\hline 1 & Sangat Setuju & 3 & 5 & 15 & \multirow{6}{*}{3,67} \\
\hline 2 & Setuju & 19 & 4 & 76 & \\
\hline 3 & Cukup Setuju & 11 & 3 & 33 & \\
\hline 4 & Kurang Setuju & 2 & 2 & 4 & \\
\hline 5 & Sangat Tidak Setuju & 0 & 1 & 0 & \\
\hline & Jumlah (N) & 35 & & 128 & \\
\hline
\end{tabular}

Berdasarkan tabel diatas dapat dilihat bahwa 3 responden $(8,6 \%)$ menilai sangat setuju, 19 responden $(54,3 \%)$ menilai setuju, 11 responden $(31,4 \%)$ menilai setuju, serta 2 responden $(5,7 \%)$ menilai kurang setuju, tidak ada yang menjawab sangat tidak setuju. Sehingga diperoleh angka penafsiran 3,67 yang berada pada kategori baik. Hal ini menunjukan bahwa sosial media (BBM) membantu ibu dalam mengungkapkan pendapat. Anak dapat terbuka terhadap ibu, Keterbukaan dalam hal ini anak dapat merespon secara jujur terhadap pendapat yang telah diungkapkan oleh ibu. 
Tabel 6 Keterbukaan anak dapat merespon jujur

\begin{tabular}{|c|c|c|c|c|c|}
\hline No & Alternatif Jawaban & $f$ & $\mathbf{X}$ & $f(x)$ & $\sum f(x) / N$ \\
\hline 1 & Sangat Setuju & 7 & 5 & 35 & \multirow{6}{*}{3,91} \\
\hline 2 & Setuju & 18 & 4 & 72 & \\
\hline 3 & Cukup Setuju & 10 & 3 & 30 & \\
\hline 4 & Kurang Setuju & 0 & 2 & 0 & \\
\hline 5 & Sangat Tidak Setuju & 0 & 1 & 0 & \\
\hline & Jumlah (N) & 35 & & 137 & \\
\hline
\end{tabular}

Berdasarkan tabel diatas dapat dilihat bahwa 7 responden $(20 \%)$ menilai sangat setuju, 18 responden $(51,4 \%)$ menilai setuju, dan 10 responden $(28,6 \%)$ menilai cukup setuju, serta tidak ada yang menjawab kurang setuju atau sangat tidak setuju. Sehingga diperoleh angka penafsiran 3,91 yang berada pada kategori baik. Hal ini menunjukan sosial media (BBM) membantu anak dalam mengungkapkan pendapat secara jujur.

Melalui hasil observasi dan wawancara, diketahui bahwa ibu dalam menggunakan Blackberry Messengger mampu mengungkapkan pendapatnya pada anak. Namun ada pula ibu yang berpendapat bahwa ketika bertemu dan berbicara bersama ibu akan lebih terbuka kepada anaknya dan bisa saling jujur.

\section{b. Empati}

Empati dalam hal ini anak mampu merasakan apa yang dirasakan ibu ketika mengirim pesan melalui sosial media (BBM). "Saya bisa merasakan ketika mamah mengirim pesan, karena kadang mamah pakai emoticonemoticon kalo lagi BBMan sama saya. Jadi ya ketika mamah khawatir biasanya mamah suka bilang. Dari kata-katanya juga ketahuan kok kalau mamah lagi marah atau lagi apa. - Murni Gunawan.

Tabel 7 Empati - anak mampu merasakan perasaan ibu

\begin{tabular}{|c|c|c|c|c|c|}
\hline No & Alternatif Jawaban & $f$ & $\mathbf{X}$ & $f(x)$ & $\frac{\sum \mathrm{f}(\mathrm{x})}{\mathrm{N}}$ \\
\hline 1 & Sangat Setuju & 4 & 5 & 20 & \multirow{6}{*}{3,54} \\
\hline 2 & Setuju & 16 & 4 & 64 & \\
\hline 3 & Cukup Setuju & 10 & 3 & 30 & \\
\hline 4 & Kurang Setuju & 5 & 2 & 10 & \\
\hline 5 & Sangat Tidak Setuju & 0 & 1 & 0 & \\
\hline \multicolumn{2}{|r|}{ Jumlah (N) } & 35 & & 124 & \\
\hline
\end{tabular}

Berdasarkan tabel diatas dapat dilihat bahwa 4 responden $(11,4 \%)$ menilai sangat setuju, 16 responden $(45,7 \%)$ menilai setuju, 10 responden $(28,6 \%)$ menilai cukup setuju, serta 5 responden $(14,3 \%)$ menilai kurang setuju, dan tidak ada yang menjawab sangat tidak setuju. Sehingga diperoleh angka penafsiran 3,54 yang berada pada kategori baik. Hal ini menunjukan bahwa sosial media (BBM) mampu membuat anak dapat berempati kepada ibu.
Berdasarkan hasil observasi dan wawancara diketahui bahwa anak mampu memahami dan merasakan perasaan ibu ketika mengirim Blackberry Messengger. Hal ini dikarenakan mayoritas ibu menggunakan emoticon ketika mengirim pesan, sehingga anak mengetahui bagaimana perasaan ibu, selain itu dengan kata-kata yang mudah dipahami anak jadi mampu merasakan apa yang ibu rasakan ketika mengirim BBM. 


\section{c. Dukungan}

"Tentu saya sering mendukung anak saya untuk belajar, kadang saya kirim doa lewat BBM-an supaya misal lagi ujian dia bisa baca dulu. Tapi saya ga pernah ngiming-ngimingin hadiah buat anak dari dulu. Saya cuman selalu bilang apapun hasilnya kamu yang ngerasain jadi ada hadiah atau enggak kamu harus rajin belajar" Mamah Erli.

Pada indikator dukungan terdapat dua item, yaitu Ibu mendukung anak, Dukungan dalam hal ini, ibu dapat mendukung kegiatan anak.

Tabel 8 Dukungan - Ibu mendukung anak

\begin{tabular}{|c|c|c|c|c|c|}
\hline No & Alternatif Jawaban & $f$ & $\mathbf{X}$ & $f(x)$ & $\frac{\sum \mathrm{f}(\mathrm{x})}{\mathrm{N}}$ \\
\hline 1 & Sangat Setuju & 4 & 5 & 20 & \multirow{6}{*}{3,77} \\
\hline 2 & Setuju & 22 & 4 & 88 & \\
\hline 3 & Cukup Setuju & 6 & 3 & 18 & \\
\hline 4 & Kurang Setuju & 3 & 2 & 6 & \\
\hline 5 & Sangat Tidak Setuju & 0 & 1 & 0 & \\
\hline & Jumlah (N) & 35 & & 132 & \\
\hline
\end{tabular}

Berdasarkan tabel diatas dapat dilihat bahwa 4 responden $(11,4 \%)$ menilai sangat setuju, 22 responden $(62,9 \%)$ menilai setuju, 6 responden $(17,1 \%)$ menilai cukup setuju, dan 3 responden $(8,6 \%)$ menilai kurang setuju, serta tidak ada yang menjawab sangat tidak setuju. Sehingga diperoleh angka penafsiran 3,77 yang berada pada kategori baik. Hal ini menunjukan bahwa sosial media (BBM) mampu membantu ibu dalam memberikan dukungan terhadap kegiatan anak. Anak merasa didukung oleh ibu, Dukungan dalam hal ini, anak merasa bahwa ibunya mendukung kegiatan anak.

Tabel 9 Dukungan - anak merasa didukung oleh ibu

\begin{tabular}{|c|c|c|c|c|c|}
\hline No & Alternatif Jawaban & $f$ & $\mathbf{X}$ & $f(x)$ & $\frac{\sum f(x)}{N}$ \\
\hline 1 & Sangat Setuju & 6 & 5 & 30 & \multirow{6}{*}{2,8} \\
\hline 2 & Setuju & 21 & 4 & 48 & \\
\hline 3 & Cukup Setuju & 4 & 3 & 12 & \\
\hline 4 & Kurang Setuju & 4 & 2 & 8 & \\
\hline 5 & Sangat Tidak Setuju & 0 & 1 & 0 & \\
\hline & Jumlah (N) & 35 & & 98 & \\
\hline
\end{tabular}

Berdasarkan tabel diatas dapat dilihat bahawa 6 responden $(17,2)$ menilai sangat setuju, 21 responden $(60 \%)$ menilai setuju, 4 responden $(11,4 \%)$ menilai cukup setuju, serta 4 responden $(11,4 \%)$ menilai kurang setuju dan tidak ada yang menjawab sangat tidak setuju. Sehingga diperoleh angka penafsiran 2,8 yang berada pada kategori cukup baik. Hal ini menunjukan bahwa sosial media (BBM) cukup membantu sehingga anak merasa didukung oleh ibu.

Melalui hasil observasi dan wawancara diketahui bahwa mayoritas ibu pernah mengirim BBM dukungan kepada anak. Hal ini dikarenakan anak merasa dengan dukungan lewat BBM semakin membuat anak termotivasi untuk belajar.

\section{d. Kepositifan}


Pada indikator kepositifan terdapat tiga item, yaitu : Ibu perhatian pada anak

Kepositifan dalam hal ini, ibu dapat memberikan perhatiaan yang positif terhadap anak.

"Saya banyak banget ngasih perhatian akhirakhir ini, soalnya anak saya bentar lagi khan mau UN. Anak saya lagi maen saya BBM supaya ga kebanyakan main, lebih baik belajar. Kalo perhatian sih pastilah namanya ibu pasti ngasih perhatian ke anak, karena khawatir kenapakenapa sama anak pasti harus ngasih perhatian ke anak" - Ibu Ira.

Tabel 10 Kepositifan Ibu perhatian pada anak

\begin{tabular}{|c|c|c|c|c|c|}
\hline No & Alternatif Jawaban & $f$ & $\mathbf{X}$ & $f(x)$ & $\frac{\sum f(x)}{N}$ \\
\hline 1 & Sangat Setuju & 9 & 5 & 45 & \multirow{6}{*}{3,86} \\
\hline 2 & Setuju & 15 & 4 & 60 & \\
\hline 3 & Cukup Setuju & 9 & 3 & 27 & \\
\hline 4 & Kurang Setuju & 1 & 2 & 2 & \\
\hline 5 & Sangat Tidak Setuju & 1 & 1 & 1 & \\
\hline & Jumlah (N) & 35 & & 135 & \\
\hline
\end{tabular}

Berdasarkan tabel diatas dapat dilihat bahwa 9 responden $(25,7 \%)$ menilai sangat setuju, 15 $(42,8 \%)$ responden menilai setuju, 9 responden $(25,7 \%)$ menilai cukup setuju, 1 responden $(2,9 \%)$ menilai kurang setuju, dan 1 responden $(2,9 \%)$ menilai sangat tidak setuju. Sehingga diperoleh angka penafsiran 3,86 yang berada pada kategori baik. Hal ini menujukan bahwa sosial media (BBM) membantu ibu dalam memberikan perhatian kepada anak. Komunikasi ibu dan anak baik, Kepositifan dalam hal ini, yaitu komunikais ibu dan anak tetap berjalan dengan baik meskipun ibu dan anak tidak dalam waktu dan tempat yang sama.

Tabel 11 Kepositifan - komunikasi ibu dan anak baik

\begin{tabular}{|c|c|c|c|c|c|}
\hline No & Alternatif Jawaban & $f$ & $\mathbf{X}$ & $f(x)$ & $\frac{\sum \mathrm{f}(\mathrm{x})}{\mathrm{N}}$ \\
\hline 1 & Sangat Setuju & 11 & 5 & 55 & \multirow{6}{*}{4,29} \\
\hline 2 & Setuju & 18 & 4 & 72 & \\
\hline 3 & Cukup Setuju & 5 & 3 & 15 & \\
\hline 4 & Kurang Setuju & 1 & 2 & 8 & \\
\hline 5 & Sangat Tidak Setuju & 0 & 1 & 0 & \\
\hline & Jumlah (N) & 35 & & 150 & \\
\hline
\end{tabular}

Berdasarkan tabel diatas dapat dilihat bahwa 11 responden $(31,4 \%)$ menilai sangat setuju. 18 responden $(51,4 \%)$ menilai setuju, 5 responden $(14,3 \%)$ menilai cukup setuju, dan 1 responden $(2,9 \%)$ menilai kurang setuju, serta tidak ada yang menjawab sangat tidak setuju. Kepositifan dalam hal ini, yaitu ibu dan anak bisa saling mengenal satu sama lain sehingga akan timbul kekompakan antara kedua belah pihak.

"Ibu sih pasti mengenal anaknya, apa yang anak mau ibu pasti tau. Saya deket sama anak saya. Soalnya khan dia satu-satunya anak cewe di rumah. Kadang saya ngasih hadiah kalo anak
Sehingga diperoleh angka penafsiran 4,29 yang berada pada kategori sangat baik. Hal ini menunjukan bahwa sosial media (BBM) sangat mampu membantu ibu dan anak dalam menjalin komunikasi.

\section{Ibu dan anak saling mengenal}

saya hapal beberapa Juz Al-Qur'an kadang handphone atau umroh. Tapi ya ga terlalu sering, soalnya khan nanti kebiasaan. Saya selalu bilang ke anak saya kalo kamu bener mau jadi dokter ya kamu harus belajar sekolah udah bagus, fasilitas juga bagus jadi ga ada alasan kamu males, jadi dokter tuh mahal jadi kamu harus bener-bener" - Mamah Jundi. 
Tabel 12 Kepositifan ibu dan anak saling mengenal

\begin{tabular}{|c|c|c|c|c|c|}
\hline No & Alternatif Jawaban & $f$ & $\mathbf{X}$ & $f(x)$ & $\frac{\sum \mathrm{f}(\mathrm{x})}{\mathrm{N}}$ \\
\hline 1 & Sangat Setuju & 6 & 5 & 30 & \multirow{6}{*}{3,8} \\
\hline 2 & Setuju & 18 & 4 & 72 & \\
\hline 3 & Cukup Setuju & 9 & 3 & 27 & \\
\hline 4 & Kurang Setuju & 2 & 2 & 4 & \\
\hline 5 & Sangat Tidak Setuju & 0 & 1 & 0 & \\
\hline & Jumlah (N) & 35 & & 133 & \\
\hline
\end{tabular}

Berdasarkan tabel diatas dapat dilihat bahwa 6 responden $(17,1 \%)$ menilai sangat setuju, 18 responden $(51,4 \%)$ menilai setuju, 9 responden $(25,7 \%)$ menilai cukup setuju, dan 2 responden $(5,7 \%)$ menilai kurang setuju, serta tidak ada yang menjawab sangat tidak setuju. Sehingga diperoleh angka penafsiran 3,8 yang berada pada kategori baik. Hal ini menunjukan bahwa sosial media (BBM) mampu membantu ibu dan anak saling mengenal.

Melalui hasil observasi dan wawancara diketahui bahwa ibu sering memberikan perhatian kepada anaknya selain itu melalui BBM pula ibu semakin mengenal sifat anak. Hal ini dikarenakan terdapat recent update pada Blackberry, karena terkadang anak mampu mengungkapkan pendapatnya dengan update status pada Blackberrynya. Sehingga ibu mengetahui apa yang sedang dirasakan oleh anak, hal tersebutlah yang membuat ibu dapat lebih mengenal anaknya.

\section{e. Kesamaan}

"Ya, supaya anak ngerti pasti saya ngirim pesan sesimpel mungkin ga bertele-tele. Kadang kalo anak lagi males belajar ya saya ngirim BBM-nya pakai kata-kata yang bikin semangat bukan marah-marah nanti tambah bt anaknya. Ya intinya sih anak saya tuh suka kalo dipuji puji kalo BBMan tuh, ga bisa dikerasin. - Ibu Reni

Pada variabel ini terdapat dua item, yaitu :

Anak mengerti isi pesan ibu

Kesamaan dalam hal ini, anak mampu mengerti isi pesan yang disampaikan oleh ibu.

Tabel 13 Kesamaan - anak mengerti isi pesan ibu

\begin{tabular}{|c|c|c|c|c|c|}
\hline No & Alternatif Jawaban & $f$ & $\mathbf{X}$ & $f(x)$ & $\sum f(x) / N$ \\
\hline 1 & Sangat Setuju & 7 & 5 & 35 & \multirow{6}{*}{3,74} \\
\hline 2 & Setuju & 17 & 4 & 68 & \\
\hline 3 & Cukup Setuju & 6 & 3 & 18 & \\
\hline 4 & Kurang Setuju & 5 & 2 & 10 & \\
\hline 5 & Sangat Tidak Setuju & 0 & 1 & 0 & \\
\hline & Jumlah (N) & 35 & & 131 & \\
\hline
\end{tabular}

Berdasarkan tabel diatas dapat dilihat bahwa 7 responden $(20 \%)$ menilai sangat setuju, 17 responden $(48,6 \%)$ menilai setuju, 6 responden $(17,1 \%)$ menilai cukup setuju, dan 5 responden $(14,3 \%)$ menilai kurang setuju, dan tidak ada yang menjawab sangat tidak setuju. Sehingga diperoleh angka penafsiran 3,74 yang berada pada kategori baik. Hal ini menunjukan bahwa sosial media (BBM) mampu membantu kesamaan isi pesan antara ibu dan anak.

\section{Anak mengerti keinginan ibu}


Kesamaan dalam hal ini, anak mampu mengerti keinginan ibu lewat isi Blackberry Messengger yang disampaikan oleh ibu.

Tabel 14 Kesamaan - Anak mengerti keinginan ibu

\begin{tabular}{|c|c|c|c|c|c|}
\hline No & Alternatif Jawaban & $f$ & $\mathbf{X}$ & $f(x)$ & $\frac{\sum \mathrm{f}(\mathrm{x})}{\mathrm{N}}$ \\
\hline 1 & Sangat Setuju & 6 & 5 & 30 & \multirow{6}{*}{3,71} \\
\hline 2 & Setuju & 17 & 4 & 68 & \\
\hline 3 & Cukup Setuju & 8 & 3 & 24 & \\
\hline 4 & Kurang Setuju & 4 & 2 & 8 & \\
\hline 5 & Sangat Tidak Setuju & 0 & 1 & 0 & \\
\hline \multicolumn{2}{|r|}{ Jumlah (N) } & 35 & & 130 & \\
\hline
\end{tabular}

Berdasarkan tabel diatas dapat dilihat bahwa 6 responden $(17,1 \%)$ menilai sangat setuju, 17 responden $(48,6 \%)$ menilai setuju, 8 responden $(22,9 \%)$ menilai cukup setuju, dan 4 responden $(11,4 \%)$ menilai kurang setuju, serta tidak ada yang menjawab sangat tidak setuju. Sehingga diperoleh angka penafsiran 3,71 yang berada pada kategori baik. Hal ini menunjukan bahwa sosial media (BBM) mampu membantu anak dalam mengerti keinginan ibu.

Melalui hasil observasi dan wawancara ibu mengirim pesan BBM semudah mungkin. Hal ini dikarenakan agar anaka mampu memahami apa yang diiinginkan ibu melalui pesan tersebut, sehingga pesan dibuat tidak berteletela dan langsung pada inti pembicaraan.

\section{Motivasi Belajar}

Motivasi belajar yang dimaksud adalah faktorfaktor apa saja yang mempengaruhi terjadinya motivasi belajar pada anak. Dalam hal ini untuk mempermudah diuraikan menjadi indikator, yakni keberhasilan (tabel 17), kebutuhan (tabel 18), harapan (tabel 19), penghargaan (tabel 2022), kegiatan dalam belajar (tabel 23-24), dan lingkungan belajar (tabel 25-26).

\section{a Keberhasilan}

Keberhasilan dalam hal ini, anak termotivasi belajar karena ingin berhasil mendapat nilai yang baik. "Kalo belajar pastinya pengen dapaet nilai yang baik, namanya orang tua kadang rada bawel BBM mulu jangan main mulu ayo belajar, jadi ya nilai bagus pasti tujuan dari belajar" - Maya Nur Arifah.

Tabel 15 Keberhasilan - mendapat nilai baik

\begin{tabular}{|c|c|c|c|c|c|}
\hline No & Alternatif Jawaban & $f$ & $\mathbf{X}$ & $f(x)$ & $\frac{\sum \mathbf{f}(\mathrm{x})}{\mathrm{N}}$ \\
\hline 1 & Sangat Setuju & 18 & 5 & 90 & \multirow{6}{*}{4,31} \\
\hline 2 & Setuju & 13 & 4 & 52 & \\
\hline 3 & Cukup Setuju & 1 & 3 & 3 & \\
\hline 4 & Kurang Setuju & 3 & 2 & 6 & \\
\hline 5 & Sangat Tidak Setuju & 0 & 1 & 0 & \\
\hline & Jumlah (N) & 35 & & 151 & \\
\hline
\end{tabular}

Berdasarkan tabel diatas dapat dilihat bahwa 18 responden $(51,4 \%)$ menilai sangat setuju, 13 responden $(37,1 \%)$ menilai setuju, 1 responden $(2,9 \%)$ menilai cukup setuju, dan 3 responden $(8,6 \%)$ menilai kurang setuju, serta tidak ada yang menjawab sangat tidak setuju. Sehingga diperoleh angka penafsiran 4,31 yang berada pada kategori sangat baik. Hal ini menunjukan bahwa mendapatkan nilai baik sangat memotivasi anak dalam belajar.

Melalui hasil wawancara dan observasi diketahui bahwa mayoritas anak di Villla Mutiara Lido setuju bahwa belajar untuk mendapatkan nilai yang baik. Selain itu pula ibu pun pernah mengirim BBM kepada anaknya 
untuk belajar agar mereka mendapatkan nilai yang baik.

\section{b Kebutuhan}

Kebutuhan dalam hal ini, anak termotivasi belajar karena kebutuhan sebab takut dimarahi oleh orang tua.
"Iya bener, mamah agak galak kalo ga belajar marah-marah mulu. Jadi ya mau gak mau harus belajar. Kalo gak dilakuin bisa dipotong uang jajan. Tapi ya selain itu pastinya supaya naik kelaslah. Segalak-galaknya mamah, kalo nilai bagus pasti dibeliin hadiah" - Bela Rachmat Pertiwi

Tabel 16 Kebutuhan - Takut dimarahi orang tua

\begin{tabular}{|c|c|c|c|c|c|}
\hline No & Alternatif Jawaban & $f$ & $\mathbf{X}$ & $f(x)$ & $\frac{\sum \mathrm{f}(\mathrm{x})}{\mathrm{N}}$ \\
\hline 1 & Sangat Setuju & 4 & 5 & 20 & \multirow{6}{*}{3,31} \\
\hline 2 & Setuju & 15 & 4 & 60 & \\
\hline 3 & Cukup Setuju & 7 & 3 & 21 & \\
\hline 4 & Kurang Setuju & 6 & 2 & 12 & \\
\hline 5 & Sangat Tidak Setuju & 3 & 1 & 3 & \\
\hline & Jumlah (N) & 35 & & 116 & \\
\hline
\end{tabular}

Berdasarkan data diatas dapat dilihat bahwa 4 responden $(11,4 \%)$ menilai sangat setuju, 15 responden $(42,9 \%)$ menilai setuju, 7 responden (20\%) menilai kurang setuju, 6 responden $(17,1 \%)$ menilai kurang setuju, dan 3 responden menilai $(8,6 \%)$ sangat tidak setuju. Sehimgga diperoleh angka penafsiran 3,31 yang berada pada kategori baik. Hal ini menunjukan bahwa ketakutan akan dimarahi oleh orang tua menjadi motivasi anak untuk belajar.

Melalui hasil observasi dan wawancara beberapa anak mengaku takut jika dimarahi orang tua mereka sehingga terkadang belajar karena rasa takut bukan karena keinginan dari diri sendiri. Hal ini membuat anak belajar hanya untuk menggugurkan kewajiban dari orang tua bukan menjadi sebuah kebutuhan bagi anak.

c. Harapan, harapan dalam hal ini, anak termotivasi belajar karena igin menambah ilmu pengetahuan sehingga harapannya anak bisa mencapai cita-cita. "Belajar ya pasti buat dapat ilmu, kalo umi sih jarang ngirim BBM nyuruh belajar. Tapi aby yang sering, ya khan kalo udah dapet ilmu jadi bisa ngerjain pelajaran yang di sekolah kalo udah bisa nilai ya otomatis bisa bagus. Kalo udah gitu citacita insya allah bisa tercapai kalau udah punya ilmunya." - Susi Inawati.

Tabel 17 Harapan - menambah ilmu pengetahuan

\begin{tabular}{|c|c|c|c|c|c|}
\hline No & Alternatif Jawaban & $f$ & $\mathbf{X}$ & $f(x)$ & $\sum f(x) / N$ \\
\hline 1 & Sangat Setuju & 16 & 5 & 80 & \multirow{6}{*}{4,29} \\
\hline 2 & Setuju & 14 & 4 & 56 & \\
\hline 3 & Cukup Setuju & 4 & 3 & 12 & \\
\hline 4 & Kurang Setuju & 1 & 2 & 2 & \\
\hline 5 & Sangat Tidak Setuju & 0 & 1 & 0 & \\
\hline & Jumlah (N) & 35 & & 150 & \\
\hline
\end{tabular}

Berdasarkan data diatas dapat dilihat bahwa 16 responden $(45,7 \%)$ menilai sangat setuju,
14 responden (40\%) menilai setuju, 4 responden $(11,4 \%)$ meniai cukup setuju, dan 1 
responden $(2,9 \%)$ menilai kurang setuju, serta tidak ada yang menjawan sangat tidak setuju. Sehingga diperoleh angka penafsiran 4,29 yang berada pada kategori sangat baik. Hal ini menunjukan bahwa menambah ilmu pengetahuan untuk mencapai cita-cita menjadi motivasi anak untuk belajar.

Melalui hasil observasi dan wawancara diketahui bahwa mayoritas anak belajar untuk mendapatkan ilmu. Hal ini dikarenakan bagi mereka kewajiban mereka untuk mendapatkan ilmu menjadikan mereka mau untuk belajar. Selain itu karena ingin cita-cita tercapai sehingga mereka mencari ilmunya agar harapan dan cita-cita dapat diraih.

\section{d Penghargaan}

"Iyalah pasti, siapa yang gak ngarepin juara, makanya mamah sering ngeBBM aku kalo lagi disekolah belajar yang bener $y a$. Ya, dapet hadiah atau pujian dari orang tua pasti pengenlah. Tapi jarang sih sekarang dapet hadiah kao waktu SD tuh sering kalo juara 1 atau 5 besar dapet hadiah tapi semenjak SMP udah gak pernah dapat hadiah lagi." - Andika Dwi Pratama.

Pada indikator ini terdapat 3 item, yaitu :

Juara

Penghargaan dalam hal ini, anak termotivasi belajar karena menginginkan juara di kelas.

Tabel 18 Penghargaan - juara kelas

\begin{tabular}{|c|c|c|c|c|c|}
\hline No & Alternatif Jawaban & $\boldsymbol{f}$ & $\mathbf{X}$ & $\boldsymbol{f}(\mathbf{x})$ & \multirow{2}{\frac{\sum\mathbf{f}(\mathbf{x})}{\mathbf{N}}}{} \\
\hline 1 & Sangat Setuju & 14 & 5 & 70 & \multirow{2}{*}{} \\
\hline 2 & Setuju & 12 & 4 & 48 & \multirow{2}{*}{$\mathbf{4 , 0 3}$} \\
\hline 3 & Cukup Setuju & 5 & 3 & 15 & \\
\hline 4 & Kurang Setuju & 4 & 2 & 8 & \multirow{2}{*}{} \\
\hline 5 & Sangat Tidak Setuju & 0 & 1 & 0 & \\
\hline & Jumlah (N) & 35 & & 141 & \\
\hline
\end{tabular}

Berdasarkan tabel diatas dapat dilihat bahwa 14 responden (40\%) menilai sangat setuju, 12 responden $(34,3 \%)$ menilai setuju, 5 responden $(14,3 \%)$ menilai cukup setuju, dan 4 responden $(11,4 \%)$ menilai kurang setuju, serta tidak ada yang menjawab sangat tidak setuju. Sehingga diperoleh angka penafsiran 4,03 yang berada pada kategori baik. Hal ini menunjukan bahwa keinginan untuk juara kelas menjadi motivasi belajar anak.

\section{Pujian}

Penghargaan dalam hal ini, anak termotivasi belajar karena menginginkan mendapat pujian dari orang tua.

Tabel 19 Penghargaan - pujian dari orang tua

\begin{tabular}{|c|c|c|c|c|c|}
\hline No & Alternatif Jawaban & $f$ & $\mathbf{X}$ & $f(x)$ & $\sum f(x) / N$ \\
\hline 1 & Sangat Setuju & 5 & 5 & 25 & \multirow{6}{*}{3,3} \\
\hline 2 & Setuju & 10 & 4 & 40 & \\
\hline 3 & Cukup Setuju & 10 & 3 & 30 & \\
\hline 4 & Kurang Setuju & 10 & 2 & 20 & \\
\hline 5 & Sangat Tidak Setuju & 0 & 1 & 0 & \\
\hline & Jumlah (N) & 35 & & 115 & \\
\hline
\end{tabular}

Berdasarkan tabel diatas dapat dilihat bahwa 5 responden $(14,2 \%)$ menilai sangat setuju, 10 responden $(28,6 \%)$ menilai setuju, 10 responden $(28,6 \%)$ menilai cukup setuju, serta 
10 responden $(28,6 \%)$ menilai kurang setuju, dan tidak ada yang menjawab sangat tidak setuju. Sehingga diperoleh angka penafsiran 3,3 yang berada pada kategori baik. Hal ini menunjukan bahwa anak mengharapkan pujian dari orang tua sehingga anak termotivasi untuk belajar.

Hadiah, Penghargaan dalam hal ini, anak termotivasi belajar karena menginginkan hadiah dari orang tua.

Tabel 20 Penghargaan - hadiah dari orang tua

\begin{tabular}{|c|c|c|c|c|c|}
\hline No & Alternatif Jawaban & $f$ & $\mathbf{X}$ & $f(x)$ & $\sum f(x) / N$ \\
\hline 1 & Sangat Setuju & 8 & 5 & 40 & \multirow{6}{*}{3,66} \\
\hline 2 & Setuju & 12 & 4 & 48 & \\
\hline 3 & Cukup Setuju & 11 & 3 & 33 & \\
\hline 4 & Kurang Setuju & 3 & 2 & 6 & \\
\hline 5 & Sangat Tidak Setuju & 1 & 1 & 1 & \\
\hline & Jumlah (N) & 35 & & 128 & \\
\hline
\end{tabular}

Berdasarkan tabel diatas dapat dilihat bahwa 8 responden $(22,9 \%)$ menilai sangat setuju, 12 responden $(34,3 \%)$ menilai setuju, 11 responden $(31,4 \%)$ menilai cukup setuju, 3 responden $(8,6 \%)$ menilai kurang setuju, dan 1 responden $(2,8 \%)$ menilai sangat tidak setuju. Sehinggadiperoleh angka penafsiran 3,66 yang berada pada kategori baik. Hal ini menunjukan bahwa hadiah dari orang tua mampu membuat anak menjadi termotivasi belajar.

Melalui hasil observasi dan wawancara mayoritas anak ingin menjadi juara di kelasnya. Namun, tidak semua anak mengharapkan pujian dan hadiah dari anaknya, hal ini disadari pada anak pada jenjang SMP hingga SMA. Hal ini terjadi karena mereka merasa pujian dan hadiah diberikan ketika mereka masih kecil, namun seiring waktu mereka menyadari bahwa belajar bukan untuk mengejar pujian dan hadiah.

\section{e Kegiatan dalam belajar}

"Guru-guru, temen-temennya asik buat diajak belajar. Tapi ya kadang ada juga yang nyebelin. Gurunya juga enak gak ngebosenin cara ngajarnya, ya bikin termotivasilah buat belajar, tapi gak semua guru sih yang gitu. Tapi paling seneng kalo pelajarannya ada praktek, di lab gitu ga ngebosenin kalo belajarnya kaya gitu" Rifani Rizki Amelia

Pada indikator ini terdapat dua item, yaitu : Kegiatan belajar menyenangkan, Kegiatan belajar dalam hal ini, anak menyukai kegiatan belajar karena menyenangkan sehingga dapat termotivasi

Tabel 21 Kegiatan dalam belajar - kegiatan menyenangkan

\begin{tabular}{|c|c|c|c|c|c|}
\hline No & Alternatif Jawaban & $f$ & $\mathbf{X}$ & $f(x)$ & $\frac{\sum \mathrm{f}(\mathrm{x})}{N}$ \\
\hline 1 & Sangat Setuju & 6 & 5 & 30 & \multirow{6}{*}{3,88} \\
\hline 2 & Setuju & 20 & 4 & 80 & \\
\hline 3 & Cukup Setuju & 8 & 3 & 24 & \\
\hline 4 & Kurang Setuju & 1 & 2 & 2 & \\
\hline 5 & Sangat Tidak Setuju & 0 & 1 & 0 & \\
\hline & Jumlah (N) & 35 & & 136 & \\
\hline
\end{tabular}


Berdasarkan tabel diatas dapat dilihat bahwa 6 respnden $(17,1 \%)$ menilai sangat setuju, 20 responden $(57,1 \%)$ menilai setuju, 8 responden $(22,9 \%)$ menilai cukup setuju, dan 1 responden (2,9\%) menilai kurang stuju, serta tidak ada yang menjawab sangat tidak setuju. Sehingga diperoleh angka penafsiran 3,88 yang berada pada kategori baik. Hal ini menunjukan bahwa kegiatan belajar yang menyenangkan mampu membuat anak termotivasi belajar.

Kegiatan belajar tidak membosankan, Kegiatan belajar dalam hal ini, anak menyukai kegiatan belajar tidak membosankan sehingga dapat termotivasi untuk belajar.

Tabel 22 Kegiatan dalam belajar - tidak membosankan

\begin{tabular}{|c|c|c|c|c|c|}
\hline No & Alternatif Jawaban & $f$ & $\mathbf{X}$ & $f(x)$ & $\sum f(x) / N$ \\
\hline 1 & Sangat Setuju & 8 & 5 & 40 & \multirow{6}{*}{3,86} \\
\hline 2 & Setuju & 14 & 4 & 56 & \\
\hline 3 & Cukup Setuju & 13 & 3 & 39 & \\
\hline 4 & Kurang Setuju & 0 & 2 & 0 & \\
\hline 5 & Sangat Tidak Setuju & 0 & 1 & 0 & \\
\hline \multicolumn{2}{|r|}{ Jumlah (N) } & 35 & & 135 & \\
\hline
\end{tabular}

Berdasarkan tabel diatas dapat dilihat bahwa 8 responden $(22,9 \%)$ menilai sangat setuju, 14 responden (40\%) menilai setuju, dan 13 responden $(37,1 \%)$, serta tidak ada yang menjawab kurang setuju atau sangat tidak setuju. Sehingga diperoleh angka penafsiran 3,86 yang berada dalam kategori baik. Hal ini menunjukan kegiatan belajar yang tidak membosankan mampu membuat anak termotivasi belajar.

Melalui hasil observasi dan wawancara dikethui bahwa berapa anak mengatakan bahwa kegiatan belajar mereka menyenangkan, namun beberapa anak berpendapat ada pula kegiatan belajar membosankan. Dalam hal ini anak menyukai belajar tidak hanya berupa teori namun juga praktek, sehingga mereka mampu mengaplikasikannya pada kehidupan dan mereka mampu mengetahui untuk apa mereka belajar.

\section{f Lingkungan belajar}

"Mamah pasti paling ngedukung saya buat belajar, cukup sering mamah ngasih saya dukungan lewat BBM. Suka bilang sekolah khan udah enak kayak yang aku mau jadi harus rajin ya belajarnya. Lingkungan sekolah juga nyaman dan aman belajar juga enak ga ngebetein, yah pokonya asiklah." -Fitria Dara Kurnia.

Pada indikator ini terdapat dua item, yaitu : Dukungan dari sekeliling, Lingkungan belajar dalam hal ini, anak merasa didukung oleh orang tua, guru, dan teman sehingga anak termotivasi belajar.

Tabel 23 Lingkungan belajar - dukungan sekeliling

\begin{tabular}{|c|c|c|c|c|c|}
\hline No & Alternatif Jawaban & $f$ & $\mathbf{X}$ & $f(x)$ & $\frac{\sum \mathrm{f}(\mathrm{x})}{\mathrm{N}}$ \\
\hline 1 & Sangat Setuju & 15 & 5 & 75 & \multirow{6}{*}{4,31} \\
\hline 2 & Setuju & 16 & 4 & 64 & \\
\hline 3 & Cukup Setuju & 4 & 3 & 12 & \\
\hline 4 & Kurang Setuju & 0 & 2 & 0 & \\
\hline 5 & Sangat Tidak Setuju & 0 & 1 & 0 & \\
\hline \multicolumn{2}{|c|}{ Jumlah (N) } & 35 & & 151 & \\
\hline
\end{tabular}

Berdasarkan data diatas dapat dilihat bahwa 15 responden $(42,9 \%)$ menilai sangat setuju, 16 responden $(45,7 \%)$ menilai setuju, dan 4 responden $(11,4 \%)$ menilai cukup setuju serta tidak ada yang menjawab kurang setuju atau sangat tidak setuju. Sehingga diperoleh angka penafsiran 4,31 yang berada dalam kategori 
sangat baik. Hal ini menunjukan dukungan dari orang tua, guru, dan teman sangat membantu anak agar temotivasi belajar.
Lingkungan aman dan nyaman, Lingkungan belajar dalam hal ini, anak merasa lingkungan belajar aman dan nyaman sehingga anak termotivasi belajar.

Tabel 24 Lingkungan belajar - aman dan nyaman

\begin{tabular}{|c|c|c|c|c|c|}
\hline No & Alternatif Jawaban & $f$ & $\mathbf{X}$ & $f(x)$ & $\frac{\sum f(x)}{N}$ \\
\hline 1 & Sangat Setuju & 9 & 5 & 45 & \multirow{6}{*}{4,08} \\
\hline 2 & Setuju & 20 & 4 & 80 & \\
\hline 3 & Cukup Setuju & 6 & 3 & 18 & \\
\hline 4 & Kurang Setuju & 0 & 2 & 0 & \\
\hline 5 & Sangat Tidak Setuju & 0 & 1 & 0 & \\
\hline & Jumlah (N) & 35 & & 143 & \\
\hline
\end{tabular}

Berdasarkan tabel diatas dapat dilihat bahwa 9 responden $(25,7 \%)$ menilai sangat setuju, 20 responden $(57,1 \%)$ menilai setuju, dan 6 responden $(17,2 \%)$ menilai cukup setuju, serta tidak ada yang menjawabkurang setuju atau sangat tidak setuju. Sehingga diperoleh angka penafsiran 4,08 yang berada dalam kategori baik. Hal ini menunjukan bahwa lingkungan belajra yang aman dan nyaman mampu membuat anak menjadi termotivasi belajar.

Melalui hasil observasi dan wawancara diketahui lingkungan belajar mereka aman dan nyaman untuk anak belajar. Selain itu mayoritas anaka mengatakan ibulah yang memebrikan dukungan terbesar agar mereka mau untuk belajar. Hal ini dikarenakan ibu mengetahui apa yang dibutuhkan oleh anak, dan ibu ingin anaknya berhasil dan tidak ingin melihat anaknya sedih ketika gagal, sehingga anak memberikan dukungan yang besar pada anak.

\section{Rekapitulasi Operasionalisasi variabel}

Tabel 25 Rekapitulasi Operasional Variabel X

\begin{tabular}{|c|c|c|c|c|}
\hline \multicolumn{5}{|c|}{ Sosial Media Komunikasi Interpersonal Ibu dan Anak } \\
\hline No & Indikator & $\begin{array}{c}\sum f \\
(x) / \\
N\end{array}$ & $\begin{array}{l}\text { Rata } \\
\text {-Rata }\end{array}$ & $\begin{array}{c}\text { Kriteria } \\
\text { Penafsiran }\end{array}$ \\
\hline & \multicolumn{4}{|l|}{ Keterbukaan } \\
\hline 1 & Ibu mudah mengungkapkan pendapat & 3,67 & \multirow{2}{*}{3,79} & \multirow{2}{*}{ Baik } \\
\hline \multirow[t]{2}{*}{2} & Anak dapat merespon pendapat dengan jujur & 3,91 & & \\
\hline & \multicolumn{4}{|l|}{ Empati } \\
\hline \multirow[t]{2}{*}{3} & $\begin{array}{l}\text { Anak merasakan perasaan ibu ketika mengirim } \\
\text { pesan }\end{array}$ & 3,54 & 3,54 & Baik \\
\hline & Dukungan & & & \\
\hline 4 & Ibu mendukung kegiatan anak & 3,77 & \multirow{2}{*}{3,3} & \multirow{2}{*}{ Baik } \\
\hline 5 & Anak merasa didukung oleh ibu & 2,8 & & \\
\hline & \multicolumn{4}{|l|}{ Kepositifan } \\
\hline
\end{tabular}




\begin{tabular}{|c|c|c|c|c|}
\hline 6 & Ibu memberikan perhatian kepada anak & 3,86 & \multirow{3}{*}{3,96} & \multirow{3}{*}{ Baik } \\
\hline 7 & Komunikasi ibu dan anak terjalin dengan baik & 4,29 & & \\
\hline \multirow[t]{2}{*}{8} & Ibu dan anak saling mengenal & 3,8 & & \\
\hline & Kesamaan & & & \\
\hline 9 & Anak mengerti isi pesan ibu & 3,74 & \multirow{2}{*}{3,73} & \multirow{2}{*}{ Baik } \\
\hline 10 & Anak mengerti keinginan ibu & 3,71 & & \\
\hline & Total $\sum f(x) / N$ & 37,09 & 3,71 & Baik \\
\hline
\end{tabular}

Berdasarkan hasil rekapitulasi opersionalisasi variabel X pada tabel 27 , terlihat bahwa nilai rata-rata indikator pada variabel $\mathrm{X}$ yakni sosial media komunikais interpersonal ibu dan anak diperoleh angka penafsiran 3,71 (antara 3,3 4,1 ) yang diartikan berada pada kategori baik.

Tabel 26 Rekapitulasi Operasional Variabel Y

\begin{tabular}{|c|c|c|c|c|}
\hline \multicolumn{5}{|c|}{ Sosial Media Komunikasi Interpersonal Ibu dan Anak } \\
\hline No & Indikator & $\begin{array}{c}\sum_{(x) /} \\
\mathbf{N}\end{array}$ & $\begin{array}{l}\text { Rata - } \\
\text { Rata }\end{array}$ & $\begin{array}{c}\text { Kriteria } \\
\text { Penafsiran }\end{array}$ \\
\hline & \multicolumn{4}{|l|}{ Keberhasilan } \\
\hline \multirow[t]{2}{*}{1} & Anak belajar karena ingin mendapat nilai baik & 4,31 & 4,31 & Sangat Baik \\
\hline & \multicolumn{4}{|l|}{ Kebutuhan } \\
\hline \multirow[t]{2}{*}{2} & Anak belajar karena takut dimarahi orang tua & 3,31 & 3,31 & Baik \\
\hline & \multicolumn{4}{|l|}{ Harapan } \\
\hline \multirow[t]{2}{*}{3} & $\begin{array}{l}\text { Anak belajar untuk menambah ilmu } \\
\text { pengetahuan }\end{array}$ & 4,29 & 4,29 & Sangat Baik \\
\hline & Penghargaan & & & \\
\hline 4 & Anak belajar karena ingin juara kelas & 4,03 & \multirow{3}{*}{3,66} & \multirow{3}{*}{ Baik } \\
\hline 5 & Anak belajar karena ingin pujian dari orang tua & 3,3 & & \\
\hline \multirow[t]{2}{*}{6} & $\begin{array}{l}\text { Anak belajar karena ingin hadiah dari orang } \\
\text { tua }\end{array}$ & 3,66 & & \\
\hline & \multicolumn{4}{|l|}{ Kegiatan Dalam Belajar } \\
\hline 7 & Kegiatan belajar menyenangkan & 3,88 & \multirow{2}{*}{3,87} & \multirow{2}{*}{ Baik } \\
\hline \multirow[t]{2}{*}{8} & Kegiatan belajar menyenangkan & 3,86 & & \\
\hline & Lingkungan Belajar & & & \\
\hline 9 & $\begin{array}{l}\text { Anak belajar karena ada dukungan dari } \\
\text { sekeliling }\end{array}$ & 4,31 & \multirow{2}{*}{4,19} & \multirow{2}{*}{ Baik } \\
\hline 10 & $\begin{array}{l}\text { Anak belajar karena lingkungan aman dan } \\
\text { nyaman }\end{array}$ & 4,08 & & \\
\hline
\end{tabular}




\begin{tabular}{|c|c|c|c|c|}
\hline Total $\Sigma \mathbf{f}(\mathbf{x}) / \mathbf{N}$ & 39,03 & 3,90 & Baik \\
\hline
\end{tabular}

Berdasarkan hasil rekapitulasi operasionalisasi variabel Y pada tabel 28, terlihat bahwa nilai rata-rata indikator pada variabel $\mathrm{Y}$ yakni motivasi belajar pada anak diperoleh angka penafsiran 3,90 (antara 3,3 - 4,1) yang dapat diartikan berada dalam kategori baik.
Uji Hipotesis, Uji hipotesis untuk mengetahui hubungan antara sosial media komunikasi interpersonal ibu dan anak dengan motivasi belajar secara menyeluruh berdasarkan uji korelasi product moment, yang dapat dilihat dari tabel dibawah ini :

Tabel 27 Hasil SPSS Pengaruh Sosial Media Komunikasi Interpersonal Ibu Dan Anak Dalam membangun Motivasi Belajar Di Villa Mutiara Lido Blok F Bogor

\begin{tabular}{|cc|c|c|}
\hline & & $\begin{array}{c}\text { Sosial Media } \\
\text { Komunikasi } \\
\text { Interpersonal }\end{array}$ & Motivasi belajar \\
\hline Sosial Media & Pearson correlation & 1 & $\mathbf{2 3 9}$ \\
Komunikasi & Sig. 2 (tailed) & 35 & $\mathbf{1 6 7}$ \\
Interpersonal & $\mathrm{N}$ & $\mathbf{3 5}$ & 1 \\
\hline & Pearson correlation \\
Motivasi belajar & Sig. 2 (tailed) & $\mathbf{2 3 9}$ & 35 \\
& $\mathrm{~N}$ & 35 & \\
\hline
\end{tabular}

Berdasarkan tabel 27 diatas analisis product moment antara sosial media komunikasi interpersonal ibu dan anak dengan motivasi belajar didapat koefisien sebesar 0,239. Nilai koefisien korelasi (r) didapat sebesar 0,239 yang terletak diantara wilayah 0,20-0,39 yang berada di level rendah, maka dapat disimpulkan bahwa korelasi diantara kedua variabel $\mathrm{X}$ (sosial media komunikasi interpersonal) dan variabel Y (motivasi belajar) memiliki hubungan yang rendah dan menunjukan hubungan negatif.

Uji Signifikansi, Hasil perhitungan diperoleh nilai $t_{\text {hitung }}$ hasil penelitian sebesar 1,77

\section{KESIMPULAN DAN SARAN}

\section{Kesimpulan}

Berdasarkan uraian hasil penelitian pada bab-bab sebelumnya, maka dapat disimpulkan sebagai berikut :

Pengaruh sosial media komunikasi interpersonal ibu dan anak dalam membangun motivasi belajar pada anak di Villa Mutiara Lido kemudian nilai $t_{\text {hitung }}$ dibandingkan dengan $t_{\text {tabel }}$ distribusi $t$ dengan taraf signifikan $5 \%(0,05)$ maka diperoleh nilai $t_{\text {tabel }}$ adalah 0,344 . Hal tersebut menunjukan bahwa ternyata $\mathrm{T}_{\text {hitung }}<$ $\mathrm{T}_{\text {tabel. }}$ Dengan demikian maka dapat disimpulkan bahwa tidak terdapat pengaruh yang nyata antara sosial media komunikasi interpersonal ibu dan anak dengan motivasi belajar, sehingga Ha ditolak dan Ho diterima. Jadi dapat disimpulkan bahwa tidak terdapat pengaruh nyata antara sosial media komunikasi interpersonal ibu dan anak dalam membangun motivasi belajar di Villa Mutiara Lido Blok F bogor.

Blok F Bogor dipengaruhi oleh (a) sosial media komunikasi interpersonal (Blackberry Messengger) dapat terjadi karena adanya : keterbukaan, empati, dukungan, kepositifan, dan kesamaan. (b) Motivasi belajar pada anak dapat terjadi karena adanya : keberhasilan, kebutuhan, harapan, penghargaan, kegiatan dalam belajar, dan lingkungan belajar.

Pengaruh sosial media komunikasi interpersonal ibu dan ank dalam membangun motivasi belajar pada anak di Villa Mutiara Lido Blok F Bogor sebesar 0,239 yang berada 
diantara wilayah (0,20-0,39), hal ini menunjukan bahwa korelasi diantara kedua variabel $\mathrm{X}$ (sosial media komunikasi interpersonal) dan variabel Y (motivasi belajar) memiliki hubungan yang rendah dan menunjukan hubungan negatif.

\section{Saran}

Berdasarkan dari hasil penelitian pada bab sebelumnya, terdapat beberapa saran yang dapat penulis kemukakan :

Orang tua khususnya ibu diharapkan mampu mengawasi anaknya dalam penggunaan Blackberry Messengger, sebab dalam Blackberry

\section{DAFTAR PUSTAKA}

\section{Sumber Buku :}

Baron A. Robert, Byrne Donn. 2004. Psikologi Sosial, Jakarta (ID) : Erlangga.

Bowlby. 1969. Attachment Theory. France (FR) : Taylor and Francis.

Budyatna, Muhammad. Ganiem Mona Leila. 2014. Teori Komunikasi Antarpribadi, Jakarta (ID) : Kencana Prenada Media Group.

Bungin, Burhan. 2008. Penelitian Kualitatif, Jakarta (ID) : Kencana.

Devito. A Joseph. 2010. Komunikasi Interpersonal. Tanggerang (ID): Kasrisma Publishing.

Gunarsa D, Singgih. 2004. Psikologi Perkembangan Anak dan Remaja. Jakarta (ID) : Gunung Mulya

Jack, Fraenklen. Wallen E, Norman. 2008. How to Design and Evalute Researche in Education. New York (US): Mc Graw-Hill Inc.

Kaplan, A. Haenlein, M. 2010. Users of the world, unite! The challenges and opportunities of Social Media, Buiness Horizon (UKA): Indiana University.

Kartono, Kartini. 2007. Psikologi Anak. Bandung (ID): Mandar Maju.

Maslow, Abraham. 1957. Motivasi dan Kepribadian. Jakarta (ID) : Pustaka Binaman Pressindo.
Messengger segala informasi dapat masuk baik informasi yang layak dibaca oleh anak maupun tidak.

Pada anak diperlukan kontrol diri dalam penggunaan fitur Blackberry Messengger sehingga tidak berlebihan dalam penggunaan Blackberry Messengger yang dapat menimbulkan kecanduan.

Komunikasi yang terbaik bagi ibu untuk membangun motivasi belajar pada anak adalah komunikasi interpersonal (face to face), sebab media komunikasi yaitu Blackberry Messengger tidak selalu dapat memberikan pengaruh pada anak ketika melakukan komunikasi.

Mulyana, Deddy. 2000. Ilmu Komunikasi : Suatu Pengantar. Bandung (ID): Remaja Rosdakarya

Puspokusumo, Aryanti. 2011. Metode Penelitian Public Relatios Kuantitatif dan Kualitatif, Jakarta (ID): Rajawali Pers.

Rakhmat, Jallaludin. 2008. Psikologi Komunikasi. Bandung (ID) : Remaja Rosdakarya.

Sardiman. 2007. Interaksi dan Motivasi Belajar Mengajar. Jakarta (ID) : Raja Grafindo Persada.

Singarimbun, Masri. Effendi Sofian. 2011. Metode Penelitian Survey. Jakarta (ID) : Pustaka LP3ES.

Singgih, Santoso. 2005. Statistik Dengan SPSS, Jakarta (ID) : Elex Media Komputindo

Sugiyono. 2012. Pengantar. Metode Penelitian Kuantitatif Kualitatif R\&D. Bandung (ID) : Alfabeta.

Suryabrata, Sumardi. $1990 . \quad$ Psikologi Pendidikan. Jakarta : Rajawali

Thoha, Miftah. 2009. Perilaku Organisasi : Konsep Dasar dan Aplikasinya. Jakarta (ID) : Rajawali Pers.

Uno, H. Hamzah B. 2010. Teori Motivasi dan Pengukurannya : Analisis Di Bidang Pendidikan. Jakarta (ID) : Bumi Aksara.

Zukifli. 2009. Psikologi Perkembangan. Bandung (ID) : Remaja Rosdakarya

\section{Sumber Skripsi :}


Gusliza, Novia. 2013. Hubungan Komunikasi Interpersonal Dengan Kepuasan Kerja Pegawai Dinas Pendidikan Pemuda dan Olahraga Kota Bukit Tinggi. [SKRIPSI]. Bandung (ID): FIP UNP skripsi : Program Studi Administrasi Pendidikan.

Rusmadi, Rushela Heldayani. 2013. Hubungan Antara Motivasi Mahasiswa Komunikasi Strata Satu dengan Perilaku Kecanduan dalam Menggunakan Fitur Blackberry Messengger di Bogor. [SKRIPSI]. Bogor (ID) : Universitas Djuanda Bogor.

Sudrajat, Harry. Zein, Duddy. Gemiharto, Ilham. 2012. Komunikasi Antarpribadi Pengguna Blackberry Dalam Pemenuhan Kebutuhan Hubungan Antarpribadi Pelajar SMA Negeri 15 Bandung. [SKRIPSI]. Bandung (ID) : Universitas Padjdjaran.

Sultoni, Ahmad. 2013.Pengaruh Pemanfaatan Internet Sebagai Sumber Belajar Sejarah Terhadap Motivasi Belajar Siswa Kelas XI IPS SMAN 1 Wiradesa Kabupaten Pekalongan Tahun Pelajaran 2011/2012. [SKRIPSI]. Semarang (ID):: Universitas Negeri Semarang.

Sholichah, Mar'atus. 2012. Pengaruh Iklim Komunikasi Organisasi Terhadap Kinerja
Pegawai. [skripsi]. Yogyakarta (ID): Universitas Islam Negeri Sunan Kalijaga Yogyakarta.

\section{Sumber Internet :}

http://id.wikipedia.org/wiki/BlackBerry_Mess enger (diakses pada tanggal 2 Pebruari 2015).

http://id.wikipedia.org/wiki/Media_sosial (diakses pada tanggal 23 Januari 2015).

http://tekno.kompas.com/read/2014/09/30/ 1304471/blackberry.umumkan.jumlah.peng guna. aktif.bbm (diakses pada tanggal 3 Pebruari 2015).

http://trendtek.republika.co.id/berita/trendte k/aplikasi/14/12/09/ngbo88-79-persenpemilik-ponsel-pintar-penggunaemblackberry-messenger (diakses pada tanggal 3 Pebruari 2015).

http://www.romelteamedia.com/2014/04/me dia-sosial-pengertiankarakteristik.html (diakses pada tanggal 23 Januari 2015).

http://www.uptekno.com/2013/09/sejarahlahirnya-blackberry-messenger.html (diakses pada tanggal 26 Januari 2015). 